\title{
TEKNOLOGI PENINGKATAN KEMAMPUAN RELAWAN DALAM PEMBERIAN LAYANAN DUKUNGAN PSIKOSOSIAL DI BADAN AMIL ZAKAT NASIONAL TANGGAP BENCANA PROVINSI JAWA BARAT
}

\author{
Rhisma Octaviany \\ Politeknik Kesejahteraan Sosial Bandung \\ Email : rhismaoctaviany@gmail.com \\ Dede Kuswanda \\ Politeknik Kesejahteraan Sosial Bandung \\ Email : dede_stks@yahoo.co.id \\ Milly Mildawati \\ Politeknik Kesejahteraan Sosial Bandung \\ Email : millystks@gmail.com
}

\begin{abstract}
Psychosocial Support Services can be defined as assistance provided to individuals and communities experiencing psychological disasters, where this assistance is carried out continuously and influences each other between psychological and social aspects in the environment where individuals or communities are located, provided to individuals and functions as motivate. The objectives of this study were to: 1) understand and understand the description of the initial conditions for increasing the ability of volunteers to provide psychosocial support at BAZNAS Disaster Response, West Java Province; 2) formulating the idea of a model for increasing the capacity of volunteers in providing psychosocial support services at BAZNAS Disaster Response, West Java Province; and 3) formulating the final model of technology to increase the capacity of volunteers in providing psychosocial support services at BAZNAS Disaster Response, West Java Province. The method in this study uses a qualitative method with a descriptive approach. Sources of data in research using secondary data sources. The data technique uses documentation studies and in-depth interviews or primary data. Checking the validity of the data used is checking the validity of trust (credibility), transferability (transferability), dependability (dependence), and certainty (confirmation). The data analysis technique used in this research is qualitative data analysis techniques and Expert Judgment. The results showed that psychosocial support services for survivors and volunteers were very important. The main role of volunteers as psychosocial workers is no less important in dealing with the survivors' psychosocial problems in the disaster healing process. However, not many volunteers have the ability to perform psychosocial support services technically, so through this study researchers tried to help volunteers to improve their ability to provide Psychosocial Support Services through the Application of the Concept of Psychosocial Support Services for BAZNAS Volunteers in West Java Province. Through this application, volunteers can more easily learn the concept of Psychosocial Support Services anytime and anywhere, given that the activities and activities of BAZNAS Disaster Response Volunteers are more in the field.
\end{abstract}

Keywords : Psychosocial Support Services, Volunteers, and Applications Psychosocial Support Service 


\begin{abstract}
Abstrak
Layanan Dukungan Psikososial dapat diartikan sebagai bantuan yang diberikan kepada individu dan masyarakat yang mengalami gangguan psikologis akibat bencana, dimana bantuan ini dilakukan secara terus menerus dan saling mempengaruhi antara aspek psikologis dan aspek sosial dalam lingkungan dimana individu atau masyarakat berada, yang diberikan kepada individu dan berfungsi sebagai memotivasi. Tujuan penelitian ini adalah untuk : 1) mengetahui dan memahami gambaran mengenai kondisi awal teknologi peningkatan kemampuan Relawan dalam pemberian layanan dukungan psikososial di BAZNAS Tanggap Bencana Provinsi Jawa Barat; 2) merumuskan gagasan model teknologi peningkatan kemampuan Relawan dalam pemberian layanan dukungan psikososial di BAZNAS Tanggap Bencana Provinsi Jawa Barat; dan 3) merumuskan model akhir teknologi peningkatan kemampuan Relawan dalam pemberian layanan dukungan psikososial di BAZNAS Tanggap Bencana Provinsi Jawa Barat. Metode dalam penelitian ini menggunakan Metode Kualitatif dengan Pendekatan Deskriptif. Sumber data dalam penelitian menggunakan sumber data sekunder. Teknik pengumpulan data menggunakan studi dokumentasi dan wawancara mendalam atau data primer. Pemeriksaan keabsahan data yang digunakan adalah pemeriksaan keabsahan kepercayaan (credibility), keteralihan (transferability), ketergantungan (dependability), dan kepastian (confirmability). Teknik analisa data yang digunakan dalam penelitian ini adalah teknik analisis data kualitatif dan Expert Judgment. Hasil Penelitian menunjukkan bahwa Layanan Dukungan Psikososial bagi penyintas ataupun relawan sangatlah penting. Peran utama para relawan sebagai pekerja psikososial tidak kalah pentingnya dalam penanganan masalah psikososial penyintas dalam proses penyembuhan pasca bencana. Namun tidak banyak relawan yang memiliki kemampuan dalam melakukan Layanan Dukungan Psikososial secara teknis, sehingga melalui penelitian ini peneliti mencoba membantu para relawan untuk meningkatkan kemampuan dalam pemberian Layanan Dukungan Psikososial melalui Aplikasi Konsep Layanan Dukungan Psikososial Relawan BAZNAS Tanggap Bencana Provinsi Jawa Barat. Melalui aplikasi ini relawan dapat lebih mudah mempelajari konsep Layanan Dukungan Psikososial kapanpun dan dimanapun, mengingat aktivitas dan kegiatan Relawan BAZNAS Tanggap Bencana yang lebih banyak di lapangan.
\end{abstract}

Keywords : Layanan Dukungan Psikososial, Relawan, dan Aplikasi Konsep Layanan Dukungan Psiksosoial 


\section{PENDAHULUAN}

Indonesia merupakan negara kepulauan terbesar di dunia yang terletak di antara Benua Asia dan Benua Australia serta Samudera Hindia dan Samudra Pasifik. Meskipun menyimpan keindahan alam yang sangat luar biasa, bangsa Indonesia juga menyadari bahwa wilayah nusantara ini memiliki kurang lebih 129 gunung api aktif (yang termasuk dalam ring of fire), dan berada pada pertemuan tiga lempeng tektonik aktif dunia yaitu lempeng Indo-Australia, Eurasia, serta Pasifik. Kondisi tersebut membuat Indonesia sangat berpotensi mengalami bencana alam. Disisi lain, dalam bukunya Aulia Fadhli (2019) menjelaskan bahwa Indonesia memiliki iklim tropis dan kondisi hidrologis yang dapat memicu bencana alam lainnya seperti banjir, tanah longsor, angin puting beliung, dan lain sebagainya.

Badan Nasional Penanggulangan Bencana (BNPB) mencatat sejumlah bencana diberbagai wilayah Indonesia sepanjang tahun ini, hingga 11 November 2019, dapat dilaporkan rekapitulasi bencana antara : jumlah kejadian bencana 3.200 kali terdiri atas 1.010 kali puting beliung, 680 kali banjir, 688 karhutla, 651 kali tanah longsor, 121 kali kekeringan, 26 kali gempabumi, 17 kali gelombang pasang/abrasi dan 7 kali letusan gunung api; jumlah korban akibat bencana 459 orang meninggal, 107 orang hilang, 3.290 orang luka-luka dan 5.942 .002 orang menderita \& mengungsi; kerusakan rumah akibat bencana sebanyak 62.275 unit rumah terdiri dari 14.770 unit rusak berat, 11.880 unit rusak sedang, dan 35.625 rusak ringan; kerusakan fasilitas akibat bencana sebanyak 1.884 unit terdiri dari 1.054 fasilitas pendidikan, 629 fasilitas peribadatan dan 201 fasilitas pendidikan; kerusakan kantor akibat bencana sebanyak 253 unit dan jembatan sebanyak 402 unit.

Data BNPB Provinsi Jawa Barat sendiri, menunjukkan jumlah kejadian bencana mulai Januari-September 2019 dengan total kejadian sebanyak 1.274 kejadian, diantaranya tanah longsor sebanyak 400 kejadian; kebakaran bangunan sebanyak 300 kejadian; angina putting beliung sebanyak 224 kejadian; banjir sebanyak 127 kejadian; kebakaran hutan dan lahan sebanyak 211 kejadian; dan gempa bumi sebanyak 12 kejadian. Dampak seluruh kejadian mengakibatkan 89.445 korban; 27 orang meninggal; dan 19.556 rumah yang mengalami kerusakan akibat bencana.

Undang-Undang Nomor 24 Tahun 2007, mendefinisikan mengenai jenis-jenis antara lain:

1. Bencana alam adalah bencana yang diakibatkan oleh peristiwa atau serangkaian peristiwa yang disebabkan oleh alam antara lain berupa gempa bumi, tsunami, gunung meletus, banjir, kekeringan, angin topan, dan tanah longsor.

2. Bencana non-alam adalah bencana yang diakibatkan oleh peristiwa atau rangkaian peristiwa nonalam yang antara lain berupa gagal teknologi, gagal modernisasi, epidemi, dan wabah penyakit.

3. Bencana sosial adalah bencana yang diakibatkan oleh peristiwa atau serangkaian peristiwa yang diakibatkan oleh manusia yang meliputi konflik sosial antarkelompok atau antarkomunitas masyarakat, dan teror

Badan Amil Zakat Nasional (BAZNAS) merupakan badan resmi dan satu-satunya yang dibentuk oleh pemerintah berdasarkan Keputusan Presiden RI No.8 Tahun 2001, yang memiliki tugas dan fungsi menghimpun dan menyalurkan zakat, infaq, dan sedekah (ZIS) pada tingkat nasional. BAZNAS Tanggap Bencana (BTB) Provinsi Jawa Barat sendiri 
merupakan setting praktek peneliti sebelumnya, yang merupakan unit kerja dari bidang Pendistribusian dan Pendayagunaan Badan Amil Zakat Nasional (BAZNAS) Provinsi Jawa Barat, yang bertugas mengurangi dampak bencana yang mengakibatkan kemiskinan dan menekan risiko keterparahan kemiskinan akibat bencana. Artinya saat ini BTB hanya melaksanakan Pengurangan Resiko Bencana (PRB) dan Respon Tanggap Darurat (RTD) sedangkan Pasca Bencana masih tergabung dalam RTD yang bersifat incidental.

Hal tersebut menggambarkan BTB belum mencakup ke tiga unsur dalam pelaksanaan Penanggulangan Bencana sesuai UU Nomor 24 Tahun 2007, yang meliputi Prabencana, Saat Tanggap Darurat, dan Pascabencana. Karena itu BTB tidak memiliki divisi khusus Pascabencana dalam struktuk organisasi, sehingga kegiatan dalam Pascabencana khususnya dalam hal Layanan Dukungan Psikososial (LDP) belum terlaksana.

Hal ini dikarenakan kebijakan BTB Provinsi Jawa Barat masih mengacuh pada BTB Pusat, sehingga BTB Jawa Barat mengalami kendala dalam mengubah struktur organisasi. Kenyataannya sampai saat ini BTB telah banyak berkonstribusi dalam hal penanggulangan bencana baik Prabencana, Saat Bencana, dan Pascabencana. Namun LDP belum terlaksana, dikarenakan beberapa hal sebagai berikut : (1)

Minimnya kemampuan relawan dalam pemberian LDP khususnya penerapan teknikteknik dalam LDP: (2) Belum tebentuknya Tim khusus dalam Penanggulangan Pascabencana pada bidang LDP: (3) Pemberian edukasi tentang penanggulangan bencana sudah sering di berikan kepada relawan namun untuk edukasi Pasca Bencana berupa LDP masih minim dan bersifat umum serta tidak kepada teknisnya, sehingga relawan tidak memiliki keahlian dalam bidang tersebut.
Peneliti telah memberikan pelatihan tentang LDP pada saat praktikum, namun masih mencakup teori dan belum kepada tekniknya. Berdasarkan hal tersebut kemudian dillakukan kelanjutan praktikum yaitu dengan penelitian tentang "Teknologi Peningkatan Kemampuan Relawan dalam Pemberian Layanan Dukungan Psikososial di Badan Amil Zakat Nasional Tanggap Bencana Provinsi Jawa Barat", dengan rumusan masalah

1. Bagaimana model awal Teknologi Peningkatan Kemampuan Relawan dalam Pemberian Layanan Dukungan Psikososial di BAZNAS Tanggap Bencana Provinsi Jawa Barat?

2. Bagaimana gagasan model yang diusulkan dalam Teknologi Peningkatan Kemampuan Relawan dalam Pemberian Layanan Dukungan Psikososial di BAZNAS Tanggap Bencana Provinsi Jawa Barat?

3. Bagaimana model akhir dalam Teknologi Peningkatan Kemampuan Relawan dalam Pemberian Layanan Dukungan Psikososial di BAZNAS Tanggap Bencana Provinsi Jawa Barat?

Hasil penelitian "Teknologi Peningkatan Kemampuan Relawan dalam Pemberian Layanan Dukungan Psikososial (LDP) di BAZNAS Tanggap Bencana (BTB) Provinsi Jawa Barat" ada dua antara lain :

1. Diharapkan dapat memberi sumbangan pemikiran untuk pengembangan ilmu praktik pekerjaan sosial khususnya yang berkaitan dengan peningkatan kemampuan relawan dalam pemberian Layanan Dukungan Psikososial (LDP). Serta dapat dijadikan bahan rujukan penelitian di bidang Layanan Dukungan Psikososial (LDP).

2. Sebagai masukan bagi BAZNAS Tanggap Bencana (BTB) Provinsi Jawa Barat, baik 
ditingkat daerah maupun ditingkat pusat untuk dijadikan pertimbangan atau dasar pengambilan keputusan untuk menentukan kebijakan dalam hal Pascabencana khususnya Layanan Dukungan Psikososial (LDP) berupa; ketersediaan data, ketersediaan model, meningkatnya kemampuan relawan dalam melakukan teknik-tekni LDP.

\section{Teknologi}

Dikutip dari situs Salamadian, dengan judul Pengertian Teknologi: Sejarah, Perkembangan, Manfaat \& Contoh Teknologi Terbaru (Salamadian, 2018), dijelaskan pula pengertian teknologi menurut Para Ahli diantaranya sebagai berikut :

1. Teknologi adalah pengembangan dan penerapan berbagai peralatan atau sistem untuk menyelesaikan persoalan-persoalan yang dihadapi manusia dalam kehidupan sehari-hari. (M Maryono).

2. Teknologi adalah keseluruhan metode yang secara rasional mengarah dan memiliki ciri efisiensi dalam setiap kegiatan manusia (Jacques Ellil).

3. Teknologi merupakan penerapan ilmu- ilmu perilaku dan alam serta pengetahuan lain secara bersistem dan mensistem untuk memecahkan masalah (Gary J. Anglin).

4. Teknologi didefinisikan sebagai suatu entitas benda atau bukan benda yang sengaja diciptakan secara terpadu melalui proses perbuatan, pemikiran untuk mencapai suatu nilai. $(\mathrm{NN})$

Dari pengertian diatas dapat disimpulkan teknologi adalah alat, mesin, cara, proses, kegiatan ataupun gagasan yang dibuat untuk mempermudah aktifitas manusia dalam kehidupan sehari hari.

\subsubsection{Peningkatan Kemampuan}

Menurut Adi S, (2003:67) peningkatan berasal dari kata tingkat, yang berarti lapis atau lapisan dari sesuatu yang kemudian membentuk susunan. Tingkat juga dapat berarti pangkat, taraf, dan kelas. Sedangkan peningkatan berarti kemajuan. Secara umum, peningkatan merupakan upaya untuk menambah derajat, tingkat, dan kualitas maupun kuantitas. Peningkatan juga dapat berarti penambahan keterampilan dan kemampuan agar menjadi lebih baik. Selain itu, peningkatan juga berarti pencapaian dalam proses, ukuran, sifat, hubungan dan sebagainya. (Tim Pengembang Ilmu Pendidikan FIP-UPI,2007)

Kemampuan berasal dari kata "mampu" yang mempunyai arti dapat atau bisa. Kemampuan adalah kesanggupan, kecakapan, kekuatan kita berusaha dengan diri sendiri. Sedangkan menurut Robbin kemampuan adalah kapasitas seseorang individu untuk melakukan beragam tugas dalam suatu pekerjaan. Lebih lanjutnya, Robbin mengungkapkan bahwa kemampuan (ability) adalah kecakapan atau potensi seseorang untuk menguasai keahlian dalam melakukan atau mengerjakan beragam tugas dalam suatu pekerjaan atau suatu penilaian atas tindakan seseorang. (Tim Pengembang Ilmu Pendidikan FIP-UPI,2007)

\subsubsection{Konsep Kerelawanan}

Dalam situsnya Wanaswara (2019) dengan judul "Pengertian Relawan, Definisi, dan Pendapat Ahli”, juga menjelaskan pengertian relawan menurut cendikiawan, antara lain :

1. International Labour Organization (ILO) atau Organisasi Buruh Internasional menyatakan bahwa relawan yaitu siapapun yang berada pada usia produktif dan dalam periode yang relatif singkat, bekerja tanpa upah, melakukan aktivitas yang tidak menjadi keharusannya dalam menghasilkan produk atau jasa; dan bukan di wilayah ia atau keluarga menetap.

2. Piliavin dan Siegel mengeruaikan kegiatan volunteering yakni ikut bertindak 
dalam kerangka organisasi yang berpotensi untuk menghasilkan layanan-layanan bagi seseorang, kelompok, atau masyarakat umum (taking actions within an institutional framework that potentially provide some service to one or more other people or to the community at large).

3. David Horton Smith menjabarkan dengan lebih rinci dengan menyatakan relawan adalah individu yang terlibat dalam aktivitas yang selain dorongan manusiawi (Biosocially) seperti makan, minum, dan tidur, bukan karena tuntutan ekonomi (bekerja, memperbaiki dan membangun rumah), bukan keharusan sebab sosial-politik (membayar pajak, mengikuti ujian pembuatan Surat Izin Mengemudi), melainkan dipengaruhi oleh harapan terhadap manfaat nyata atas "kebaikan" yang dihasilkaan dibandingkan melakukan kegiatan yang termaktub sebelumnya.

4. Scroeder memberikan penjelasan yang tidak terlalu berbeda dengan Myers, namun mempunyai penekenan yang lebih mendalam. Sukarelawan ialah individu yang rela menyumbangkan tenaga atau jasa, kemampuan dan waktunya tanpa mendapatkan upah secara finansial atau tanpa mengharapkan keuntungan materi dari organisasi pelayanan yang mengorganisasi suatu kegiatan tertentu secara formal. Selain itu kegiatan yang dilakukan relawan bersifat sukarela untuk menolong orang lain tanpa adanya harapan akan imbalan eksternal.

\subsubsection{Konsep Psikososial}

Teori

psikososial

menjelaskan

perkembangan manusia sebagai suatu produk interaksi antara kebutuhan-kebutuhan biologis dan psikologis individu dan kemampuankemampuan pada suatu sisi dan harapan-harapan atau tuntutan sosial pada sisi lain. Teori ini memperhitungkan pola-pola perkembangan individual yang muncul dalam proses biopsikososial. (Yeane EM, dkk 2013:15)

\subsubsection{Konsep Layanan Dukungan Psikososial}

Indonesia merupakan salah satu negara yang rentan terdampak bencana. Pemberian Dukungan Psikososial merupakan bentuk intervensi sosial yang saat ini menjadi fokus untuk dikembangkan dalam strategi pengurangan risiko bencana di Indonesia, sebagaimana tertuang pada Undang-Undang Republik Indonesia Nomor 24 Tahun 2007, tentang Penanggulangan Bencana, khususnya Pasal 6 dan pasal 8 yang telah mengamanatkan bahwa tanggung jawab Pemerintah dan Pemerintah Daerah dalam penyelenggaraan penanggulangan bencana.

Pengertian dukungan sendiri adalah bentuk sebuah suport kepada seseorang atau suatu perhatian, penghargaan sehingga layanan dukungan psikososial dapat diartikan sebagai bantuan yang diberikan kepada individu dan masyarakat yang mengalami gangguan psikologis akibat bencana, dimana bantuan ini dilakukan secara terus menerus dan saling mempengaruhi antara aspek psikologis dan aspek sosial dalam lingkungan dimana individu atau masyarakat berada, yang diberikan kepada individu dan berfungsi sebagai memotivasi.

Sedangkan konsep psikososial terdiri dari dua hal, yaitu "psiko" dan "sosial". Kata psiko mengacu pada jiwa, pikiran, emosi atau perasaan, perilaku, hal-hal yang diyakini, sikap, persepsi dan pemahaman akan diri. Kata sosial merujuk pada orang lain, tatanan sosial, norma, nilai aturan,system ekonomi, system kekerabatan, agama atau religi serta keyakinan yang berlaku dalam suatu masyarakat Psikososial diartikan sebagai hubungan yang dinamis dalam interaksi antara manusia, dimana tingkah laku, pikiran dan emosi individu akan 
mempengaruhi dan dipengaruhi oleh orang lain atau pengalaman sosial.

\section{METODE}

Metode dalam penelitian ini menggunakan Metode Kualitatif dengan Pendekatan Deskriptif, yaitu penelitian yang hasilnya berupa data deskriptif dan data sekunder melalui fakta-fakta dari kondisi alami sebagai sumber secara langsung dengan instrumen dari peneliti sendiri. Tujuan penelitian ini untuk mengetahui gambaran mendalam terhadap objek yang dipilih yaitu tentang bagaimana Peningkatan Relawan terhadap Layanan Dukungan Psikososial di Badan Amil Zakat Nasional (BAZNAS) Provinsi Jawa Barat.

Pendekatan penelitian kualitatif, sebagaimana yang telah didefinisikan Lexi J. moleong (2012:6) adalah penelitian yang bermaksud untuk memahami fenomena tentang apa yang dialami oleh objek penelitian. Contohnya perilaku, presepsi, motivasi, tindakan secara holistik dan dengan cara deskripsi dalam bentuk kata-kata dan bahasa, pada suatu konteks khusus yang alamiah dengan memanfaatkan berbagai metode ilmiah.

Metode deskriptif menurut Whitney (1961) dalam Nazir (2005) adalah pendekatan dengan pencarian fakta dan interprestasi yang tepat. Penelitian deskriptif mempelajari masalahmasalah dalam masyarakat, serta tata cara yang berlaku dalam masyarakat serta situasi-situasi tertentu termasuk tentang hubungan kegiatankegiatan, sikap-sikap, pandangan-pandangan, serta proses-proses yang sedang berlangsung dan pengaruh-pengaruh dari suatu fenomena. Tujuan dari metode deskriptif adalah untuk membuat deskripsi penelitian secara jelas, sistematis, dan memperoleh pemahaman yang mendalam mengenai desain metode casework dalam penanganan gangguan kecemasan celebral palsy.
Sumber data dalam penelitian ini adalah dimana peneliti memilih subjek-subjek yang relevan dengan topik penelitian, dalam hal ini sumber data yang digunakan oleh peneliti adalah sumber data sekunder. Menurut Sugiyono (2015) bahwa, Sumber data sekunder merupakan sumber yang tidak langsung memberikan data kepada pengumpul data misalnya lewat orang lain atau lewat dokumen. Salah satu contoh melalui dokumentasi atau orang lain. Sumber data sekunder yang digunakan adalah laporan seperti dokumen, buku, karya ilmiah, jurnal, arsip, foto, serta penelitian yang telah dilakukan sebelummya dan data statistik dapat mendukung dalam penelitian ini.

Cara menentukan data dalam penelitian ini yaitu Judgement Sampling (Purposive Sampling). Teknik Judgement Sampling adalah teknik penarikan sampel yang dilakukan berdasarkan karakteristik atau pertimbangan tertentu yang ditetapkan terhadap elemen populasi target yang disesuaikan dengan tujuan atau masalah penelitian (Moleong, 2011). informan terpilih dan mewakili yang dianggap mampu memberikan data-data yang dibutuhkan selama penelitian berlangsung. Penentuan informan ini mengacu pada pendapat Moleong (2011:132) yang menyatakan bahwa, "Informan adalah orang yang ada dalam latar penelitian, orang yang dimanfaatkan untuk memberikan informasi tentang situasi dan kondisi latar penelitian".

Pemerikasaan keabsahan data dilakukan dengan Uji kepercayaan (credibility), Uji keteralihan (transferability), Uji ketergantungan (dependability), dan Uji kepastian (confirmability).

Dalam penelitian kualitatif, analisis data dilaksanakan sebelum peneliti terjun ke lapangan, selama peneliti mengadakan penelitian di lapangan, sampai dengan pelaporan hasil penelitian. Analisis data dimulai sejak 
peneliti menentukan fokus penelitian sampai dengan pembuatan laporan penelitian selesai. Jadi teknik analisis data dilaksanakan sejak merencanakan penelitian sampai penelitian selesai.

Analisis data adalah proses mencari dan menyusun secara sistematis data yang diperoleh dari hasil wawancara, catatan lapangan, dan bahan-bahan lain, sehingga dapat mudah dipahami, dan temuannya dapat diinformasikan kepada orang lain. Analisis data dilakukan dengan mengorganisasikan data, menjabarkannya ke dalam unit-unit, melakukan sintesa, menyusun ke dalam pola, memilih mana yang penting dan yang akan dipelajari, dan membuat kesimpulan yang dapat diceritakan kepada orang lain (Sugiyono, 2007:224). Secara garis besar, analisis data dilakukan dengan tahapan data reduction (reduksi data), data display (penyajian data) dan conclusion drawing/verification (verifikasi/ penarikan kesimpulan).

\section{HASIL DAN PEMBAHASAN}

\section{Gambaran Lokasi Penelitian}

Badan Amil Zakat Nasional (BAZNAS) merupakan badan resmi dan satu-satunya yang dibentuk oleh pemerintah berdasarkan Keputusan Presiden RI No. 8 Tahun 2001, yang memiliki tugas dan fungsi menghimpun dan menyalurkan zakat, infaq, dan sedekah (ZIS) pada tingkat nasional. Lahirnya Undang-Undang Nomor 23 Tahun 2011 tentang Pengelolaan Zakat semakin mengukuhkan peran BAZNAS sebagai lembaga yang berwenang melakukan pengelolaan zakat secara nasional. Dalam UU tersebut, BAZNAS dinyatakan sebagai lembaga pemerintah nonstruktural yang bersifat mandiri dan bertanggung jawab kepada Presiden melalui Menteri Agama.

Setelah lahirnya undang-undang No.23 tahun 2011 tentang pengelolaan zakat yang disertai dengan terbitnya Peraturan Pemerintah
No.14 Tahun 2014 tentang pelaksanaan Undang-undang pengelolaan zakat, maka organisai di tingkat provinsi harus mengikuti ketentuan tersebut. Selanjutnya BAZNAS Provinsi Jawa Barat dibentuk oleh Menteri Agama atas usul gubernur setelah mendapat pertimbangan BAZNAS Pusat. BAZNAS Provinsi bertanggung jawab kepada BAZNAS Pusat dan pemerintah daerah provinsi dan didirikan pada tanggal 26 Januari 2015.

Baznas Tanggap Bencana (BTB) adalah unit kerja dari bidang Pendistribusian dan Pendayagunaan Badan Amil Zakat Nasional (BAZNAS) Provinsi Jawa Barat yang bertugas mengurangi dampak bencana yang mengakibatkan kemiskinan dan menekan risiko keterparahan kemiskinan akibat bencana. BTB bertujuan meningkatkan pengetahuan masyarakat tentang Pengurangan Risiko Bencana (PRB) melalui edukasi; menangani korban bencana melalui tahapan Rescue, Relief, Recovery, Recontruction; serta menumbuhkan jiwa kerelawanan di masyarakat, menguatkan kapasitas dan membangun jaringan Relawan.

\section{Pembahasan}

Seperti yang telah dijelaskan sebelumnya, penelitian "Teknologi Peningkatan Kemampuan Relawan dalam Pemberian Layanan Dukungan Psikososial di Badan Amil Zakat Nasional Tanggap Bencana Provinsi Jawa Barat", merupakan kelanjutan dari kegiatan Praktikum Magister 2018 yang dilakukan oleh peneliti di Badan Amil Zakat Nasional Tanggap Bencana Provinsi Jawa Barat. Data yang diperoleh saat praktikum peneliti merupakan data sekunder dalam penelitian ini, untuk kemudian di kembangkan demi menghasilkan sebuah model terkait Teknologi Peningkatan Kemampuan Relawan dalam Pemberian Layanan Dukungan Psikososial di BAZNAS Tanggap Bencana Provinsi Jawa Barat. 
Tanggap Bencana dalam hal LDP, menggunakan instrumen berupa pretest dan postest untuk mengukur tingkat kemampuan para relawan terkait pelatihan yang telah dilakukan. Pertanyaan dalam instrumen terkait materi tentang LDP, antara lain : 1) Apa itu LDP; 2) Tujuan dan manfaat LDP; 3) Dampak psikososial bagi individu, komunitas dan anak; 4) Faktor yang mempengaruhi kerentanan psikologis; 5) Asessmen Psikososial; 6) Ketrampilan dasar LDP; 7) Teknik-teknik LDP. Dimana setiap poin pertanyaan berisi pertanyaan yang lebih mendalam.

Dari hasil pretes dan postes pada praktikum sebelumnya, hasil penghitungan menunjukkan adanya peningkatan dalam jumlah skor, dimana skor pretes 276 meningkat di postes sebanyak 288. Walaupun hasil di atas menunjukkan adanya peningkatan, namun peneliti merasa pelatihan yang di berikan belum cukup dan belum secara teknis dan tidak sampai kepada teknik-teknik dalam Layanan Dukungan Psikososial. Maka dalam penelitian ini peneliti bermaksud untuk mengadakan pelatihan yang lebih mendalam terkait Layanan Dukungan Psikososial untuk para relawan melalui pelatihan.

Namun dalam proses penelitian ini, peneliti mengalami beberapa kendala, sehingga ada sedikit perubahan dalam penyususan ataupun pengumpulan data dalam penelitian. Dimana pada proses sebelumnya peneliti menggunakan metode Penelitian Tindakan Partisipatif atau Participatory Action Research (PAR) berubah menjadi Metode Kualitatif dengan Pendekatan Deskriptif sehingga peneliti tidak terjun langsung dalam melakukan kegiatan dilapangan. Namun dalam proses pengempulan data, peneliti tetap menggunakan data primer mengingat belum adanya penelitian terdahulu terkait Layanan Dukungan Psikososial (LDP) yang dapat digunakan oleh peneliti. Perubahan dalam proses penelitian ini dikarenakan situasi pandemi
Covid-19 yang tidak memungkinkan untuk dilakukannya kegiatan yang dapat mengumpulkan orang.

\subsection{Model Awal}

Berdasarkan hasil praktikum sebelumnya, model awal peningkatan kemampuan Relawan BAZNAS Tanggap Bencana (BTB) Provinsi Jawa Barat meliputi edukasi tentang Prabencana dan Tanggap Darurat, sedangkan Pasca Bencana dalam hal Layanan Dukungan Psikososial (LDP) masih minim dan sangat jarang diadakan, mengingat BTB Provinsi Jawa Barat hanya berfokus pada prabencana dan kedaruratan. Selain itu LDP yang di berikan tidak sampai pada teknik-teknik LDP itu sendiri, sehingga para relawan belum memiliki keahlian untuk melakukan LDP. Pelatihan terkait LDP juga tidak menghadirkan narasumber yang berkompeten di bidangnya atau ahli dalam Layanan Dukungan Psikososial. Model awal dalam Peningkatan Kemampuan Relawan dalam hal Layanan Dukungan Psikososial dapat di lihat pada bagan berikut :

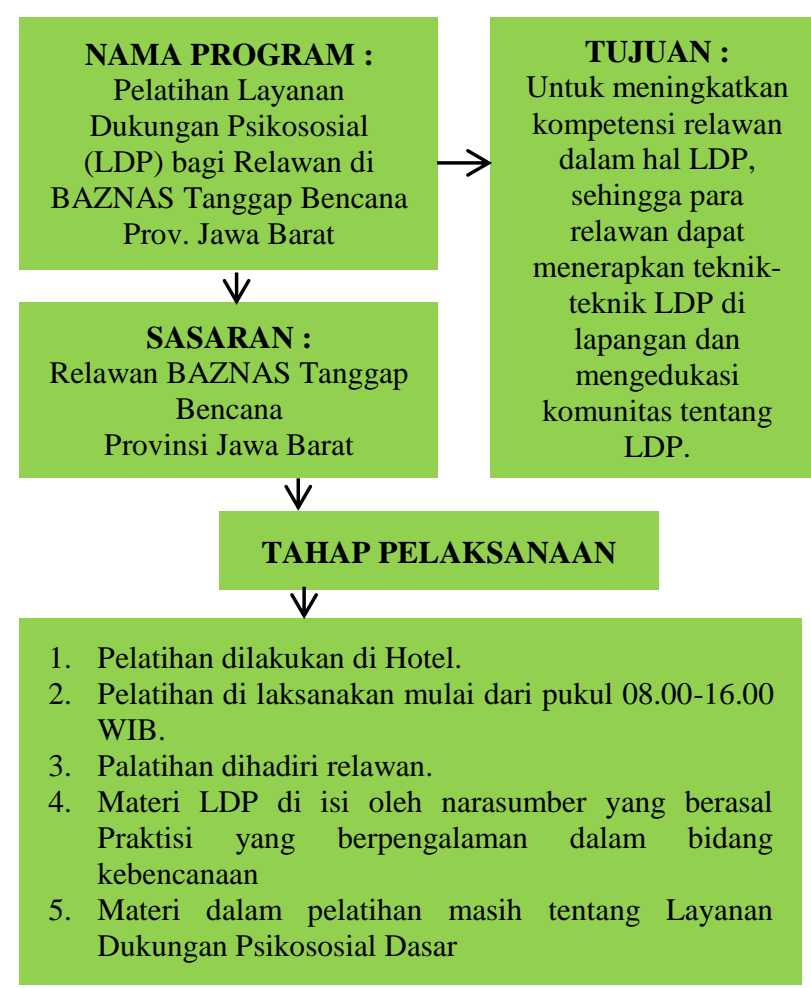

Bagan 1. Model Awal Peningkatan Kemampuan Relawan dalam hal Layanan Dukungan Psikososial 


\subsection{Model yang Diusulkan}

Berdasarkan model awal, peneliti mengusulkan kepada BAZNAS Tanggap Bencana (BTB) Provinsi Jawa Barat untuk lebih meningkatkan pemberian edukasi terkait Layanan Dukungan Psikososial (LDP) bagi relawan melalui pelatihan, dengan konsep dan narasumber yang berkompeten atau ahli di bidangnya, serta menjadikan Layanan Dukungan Psikososial sebagai salah satu program tahunan dalam kegiatan BAZNAS Tanggap Bencana Provinsi Jawa Barat, mengingat pentingnya kesehatan mental para korban bencana sehingga mereka dapat melanjutkan hidup mereka dengan baik tanpa harus terbebani dengan masalahmasalah psikososial pascabencana seperti trauma yang berkepanjangan, stress, bahkan depresi.

Selain itu, peneliti melihan potensi yang dimiliki oleh para relawan yang mendukung untuk terciptanya LDP tersebut, dikarenakan latar belakang pendidikan para relawan yang sebagian berlatarbelakang psikologi dan pekerja sosial, serta pengalaman-pengalaman relawan di lapangan. Maka dari itu, peneliti sangat mendukung untuk diadakannya kegiatan peningkatan bagi relawan dalam melakukan LDP di BTB Provinsi Jawa Barat. Adapun model yang diusulkan dapat di lihat pada bagan berikut :

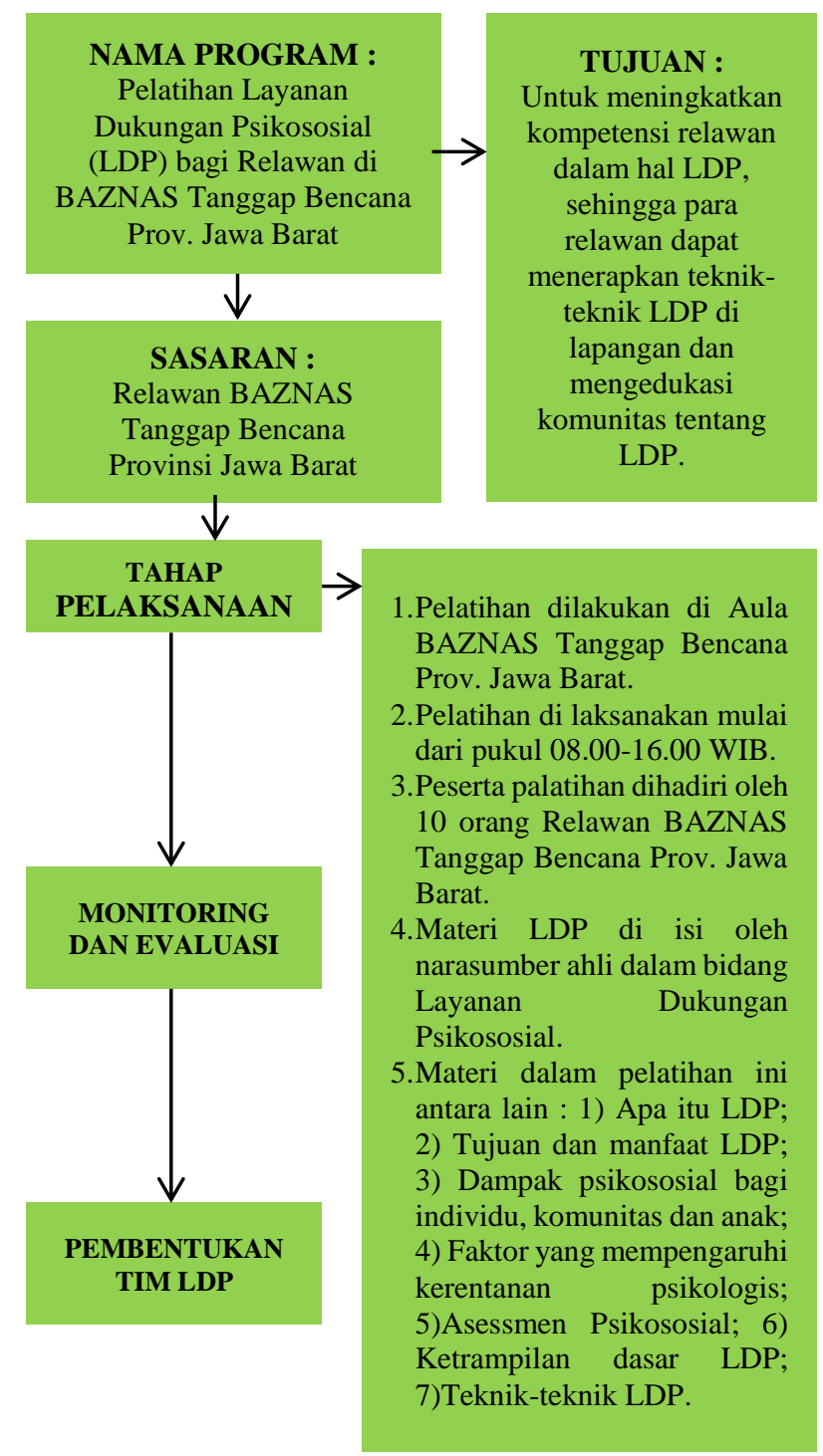

Bagan 2. Model Usulan Peningkatan Kemampuan Relawan dalam hal Layanan Dukungan Sosial

\subsection{Model Akhir}

Model akhir dari penelitian tentang "Teknologi Peningkatan Kemampuan Relawan dalam melakukan Layanan Dukungan Psikososial di BAZNAS Tanggap Bencana Provinsi Jawa Barat" ini seharusnya berdasarkan dari model yang telah diusulkan sebelumnya, yaitu melakukan pelatihan bagi para relawan BAZNAS Tanggap Bencana (BTB) Provinsi Jawa Barat dalam hal Layanan Dukungan Psikososial, dengan menghadirkan para narasumber yang berkompeten di bidangnya. Namun situasi saat ini tidak memungkinkan untuk melakukan pertemuan dalam jumlah 
banyak, mengingat situasi pandemi Covid-19 saat ini sangat dapat membahayakan orang lain.

Sehingga model akhir penelitian ini adalah menyusun sebuah pedoman dan petunjuk teknik dalam bentuk aplikasi, dimana aplikasi tersebut menyajikan berbagai pengetahuan mengenai konsen dan teknik LDP. Materi yang disajikan merupakan hasil dari wawancara menggunakan angket secara online kepada para relawan terkait kebutuhan materi yang akan disajikan (terlampir). Model akhir ini diharapkan dapat membantu relawan agar dapat selalu mengakses materi LDP dimanapun dan kapanpun relawan inginkan secara mobile.

Pengumpulan data dalam model akhir ini menggunakan instrumen dengan beberapa aspek pertanyaan sebanyak 40 pertanyaan (terlampir), dan jumlah responden sebanyak 10 orang. Penghitungan dari setiap aspek ditentukan menggunakan rumus sebagai berikut :

Nilai Tertinggi $=$ Total Skor dari masing-masing aspek

Nilai Terendah $=$ Jumlah Pertanyaan $\mathrm{x}$ Jumlah Responden

Kelas Interval $=\underline{\text { Nilai Tertinggi }- \text { Nilai Terendah }}$ Jumlah Interval (rendah, sedang, tinggi) $=3$

1. Penghitungan Aspek Pernyataan terkait Pengetahuan tentang Gangguan Psikologis Akibat Bencana.

Nilai Tertinggi $=361$

Nilai Terendah $=10 \times 9=90$

Kelas Interval $=\frac{361-90}{3}=\underline{271}=90$

Penilaian :

$\square$ Rendah $=90-180$
$\square$ Sedang $=181-271$
$\checkmark$ Tinggi $=272-362$

Dari penghitungan di atas, dapat dilihat pernyataan relawan terkait pengetahuan tentang gangguan psikologis akibat bencana berada pada penilaian $272-362$ yang berarti tinggi.

2. Penghitungan Aspek Pernyataan terkait pengetahuan tentang layanan dukungan psikososial

\begin{tabular}{|l|c|c|c|}
\hline Jenis Jawaban & SKALA & $\begin{array}{c}\text { Junlah Jawaban } \\
\text { Responden }\end{array}$ & $\begin{array}{c}\text { Total } \\
\text { Skor }\end{array}$ \\
\hline Sangat Setuju & 5 & 14 & 70 \\
\hline Setuju & 4 & 35 & 140 \\
\hline Ragu-ragu & 3 & 14 & 42 \\
\hline Tidak Setuju & 2 & 7 & 14 \\
\hline $\begin{array}{l}\text { Sangat Tidak } \\
\text { Setuju }\end{array}$ & 1 & 0 & 0 \\
\hline \multicolumn{2}{|l}{} & $\mathbf{2 6 6}$ \\
\hline
\end{tabular}

Nilai Tertinggi $=226$

Nilai Terendah $=10 \times 7=70$

Kelas Interval $=\frac{226-70}{3}=\underline{196}=65$

Penilaian :

$\square$ Rendah $=70-135$
$\square$ Sedang $=136-201$
$\checkmark$ Tinggi $=202-267$

Dari penghitungan di atas, dapat dilihat pernyataan terkait pengetahuan tentang layanan dukungan psikososial berada pada penilaian $202-267$ yang berarti tinggi.

3. Penghitungan Aspek Pernyataan terkait pengetahuan tentang Asessmen psikososial

Nilai Tertinggi $=129$

Nilai Terendah $=10 \times 3=30$

\begin{tabular}{|l|c|c|c|}
\hline Jenis Jawaban & SKALA & $\begin{array}{c}\text { Junlah Jawaban } \\
\text { Responden }\end{array}$ & $\begin{array}{c}\text { Total } \\
\text { Skor }\end{array}$ \\
\hline Sangat Setuju & 5 & 21 & 105 \\
\hline Setuju & 4 & 54 & 216 \\
\hline Ragu-ragu & 3 & 12 & 36 \\
\hline Tidak Setuju & 2 & 2 & 4 \\
\hline $\begin{array}{l}\text { Sangat Tidak } \\
\text { Setuju }\end{array}$ & 1 & 0 & 0 \\
\hline \multicolumn{2}{|r|}{} & $\mathbf{3 6 1}$ \\
\hline
\end{tabular}

Kelas Interval $=\frac{129-30}{3}=\underline{99}=33$

Penilaian :

$\begin{aligned} \square \text { Rendah } & =30-63 \\ \square \text { Sedang } & =62-95 \\ \checkmark \text { Tinggi } & =96-129\end{aligned}$


Dari penghitungan di atas, dapat dilihat pernyataan relawan terkait pengetahuan tentang asessmen psikososial berada pada penilaian $202-267$ yang berarti tinggi.

4. Penghitungan Aspek Pertanyaan terkait Praktik Asessmen Psikososial

\begin{tabular}{|l|c|c|c|}
\hline Jenis Jawaban & SKALA & $\begin{array}{c}\text { Junlah Jawaban } \\
\text { Responden }\end{array}$ & $\begin{array}{c}\text { Total } \\
\text { Skor }\end{array}$ \\
\hline Sangat Setuju & 5 & 10 & 50 \\
\hline Setuju & 4 & 19 & 76 \\
\hline Ragu-ragu & 3 & 1 & 3 \\
\hline Tidak Setuju & 2 & 0 & 0 \\
\hline $\begin{array}{l}\text { Sangat Tidak } \\
\text { Setuju }\end{array}$ & 1 & 0 & 0 \\
\hline \multicolumn{2}{|l|}{} & 129 \\
\hline
\end{tabular}

Nilai Tertinggi $=109$

Nilai Terendah $=10 \times 5=50$

Kelas Interval $=\frac{109-50}{3}=\underline{59}=19$

Penilaian :

$\begin{aligned} \square \text { Rendah } & =50-69 \\ \square \text { Sedang } & =70-89 \\ \checkmark \text { Tinggi } & =90-109\end{aligned}$

Dari penghitungan di atas, dapat dilihat pernyataan relawan terkait Praktik Asessmen Psikososial berada pada penilaian 90 - 109 yang berarti tinggi.

5. Penghitungan Aspek Pertanyaan terkait Pengetahuan tentang Kemampuan Relawan dalam Menerapkan Prinsip Pelaksanaan

\begin{tabular}{|l|c|c|c|}
\hline Jenis Jawaban & SKALA & $\begin{array}{c}\text { Junlah Jawaban } \\
\text { Responden }\end{array}$ & $\begin{array}{c}\text { Total } \\
\text { Skor }\end{array}$ \\
\hline Pernah & 3 & 19 & 57 \\
\hline Kadang-kadang & 2 & 22 & 44 \\
\hline Tidak Pernah & 1 & 8 & 8 \\
\hline \multicolumn{3}{|l|}{} & 109 \\
\hline
\end{tabular}

Layanan Dukungan Psikososial

$$
\begin{array}{ll}
\text { Nilai Tertinggi } & =260 \\
\text { Nilai Terendah } & =10 \times 9=90 \\
\text { Kelas Interval } & =\frac{260-90}{3}=\underline{170}=57
\end{array}
$$

Penilaian :

$$
\begin{aligned}
& \square \text { Rendah }=90-147 \\
& \square \text { Sedang }=148-205
\end{aligned}
$$

$\checkmark$ Tinggi $=206-263$

Dari penghitungan di atas, dapat dilihat jawaban pertanyaan terkait Pengetahuan tentang Kemampuan Relawan dalam Menerapkan Prinsip Pelaksanaan Layanan Dukungan Psikososial berada pada penilaian 206 - 263 yang berarti tinggi.

6. Penghitungan AspekPertanyaan terkait Pengetahuan tentang Kemampuan Relawan dalam Menerapkan Teknik Layanan Dukungan Psikososial

Nilai Tertinggi $=192$

Nilai Terendah $=10 \times 7=70$

Kelas Interval $=\underline{192-70}=\underline{122}=40$

$$
33
$$

Penilaian :

$$
\begin{aligned}
& \square \text { Rendah }=70-110 \\
& \square \text { Sedang }=111-151 \\
& \checkmark \quad \text { Tinggi }=152-192
\end{aligned}
$$

Dari penghitungan di atas, dapat dilihat

\begin{tabular}{|c|c|c|c|}
\hline Jenis Jawaban & SKALA & $\begin{array}{c}\text { Junlah Jawaban } \\
\text { Responden }\end{array}$ & $\begin{array}{l}\text { Total } \\
\text { Skor }\end{array}$ \\
\hline Sangat Mampu & 4 & 1 & 4 \\
\hline Mampu & 3 & 50 & 150 \\
\hline Kurang Mampu & 2 & 19 & 38 \\
\hline \multirow[t]{2}{*}{ Tidak Mampu } & 1 & 0 & 0 \\
\hline & & & 192 \\
\hline Jenis Jawaban & SKALA & $\begin{array}{c}\text { Junlah Jawaban } \\
\text { Responden }\end{array}$ & $\begin{array}{l}\text { Total } \\
\text { Skor }\end{array}$ \\
\hline Sangat Mampu & 4 & 7 & 28 \\
\hline Mampu & 3 & 66 & 198 \\
\hline Kurang Mampu & 2 & 17 & 34 \\
\hline Tidak Mampu & 1 & 0 & 0 \\
\hline & & & $26 \theta 1$ \\
\hline
\end{tabular}
jawaban pertanyaan terkait Pengetahuan tentang Kemampuan Relawan dalam Menerapkan Teknik Layanan Dukungan Psikososial berada pada penilaian 152 - 192 yang berarti tinggi.

7. Penghitungan Seluruh Aspek Pernyataan dan Pertanyaan dalam Instrumen Layanan Dukungan Psikososial 


\begin{tabular}{|c|c|c|c|c|c|c|c|c|c|c|c|}
\hline \multirow{3}{*}{ SOAL } & \multicolumn{10}{|c|}{ NOMOR RESPONDEN } & \multirow{3}{*}{ JUMLAH } \\
\hline & $\mathbf{R}$ & $\mathbf{R}$ & $\mathbf{R}$ & $\mathbf{R}$ & $\mathbf{R}$ & $\mathbf{R}$ & $\mathbf{R}$ & $\mathbf{R}$ & $\mathbf{R}$ & $\mathbf{R}$ & \\
\hline & 1 & 2 & 3 & 4 & 5 & 6 & 7 & 8 & 9 & 10 & \\
\hline \multicolumn{11}{|c|}{$\begin{array}{c}\text { Daftar Pernyataan terkait Pengetahuan tentang } \\
\text { Gangguan Psikologis Akibat Bencana }\end{array}$} & \\
\hline 1 & 5 & 5 & 4 & 4 & 4 & 5 & 4 & 5 & 5 & 5 & 46 \\
\hline 2 & 4 & 5 & 4 & 4 & 4 & 4 & 4 & 4 & 4 & 5 & 42 \\
\hline 3 & 4 & 5 & 4 & 4 & 4 & 4 & 4 & 4 & 4 & 4 & 41 \\
\hline 4 & 4 & 4 & 4 & 4 & 4 & 4 & 4 & 4 & 4 & 4 & 40 \\
\hline 5 & 3 & 5 & 4 & 5 & 4 & 3 & 2 & 5 & 3 & 2 & 36 \\
\hline 6 & 3 & 5 & 3 & 5 & 4 & 3 & 4 & 4 & 3 & 3 & 37 \\
\hline 7 & 4 & 5 & 4 & 5 & 3 & 4 & 3 & 4 & 3 & 4 & 39 \\
\hline 8 & 4 & 5 & 4 & 5 & 4 & 4 & 4 & 4 & 5 & 4 & 43 \\
\hline 9 & 4 & 5 & 4 & 5 & 3 & 4 & 4 & 4 & 5 & 4 & 42 \\
\hline \multicolumn{11}{|c|}{ Total Skor } & 366 \\
\hline \multicolumn{11}{|c|}{$\begin{array}{c}\text { Daftar pernyataan terkait pengetahuan tentang } \\
\text { layanan dukungan psikososial }\end{array}$} & \\
\hline 10 & 4 & 5 & 4 & 5 & 4 & 3 & 2 & 3 & 4 & 4 & 38 \\
\hline 11 & 4 & 5 & 4 & 5 & 4 & 3 & 2 & 3 & 4 & 4 & 38 \\
\hline 12 & 4 & 5 & 4 & 5 & 4 & 3 & 2 & 3 & 4 & 4 & 38 \\
\hline 13 & 4 & 5 & 4 & 5 & 4 & 3 & 2 & 3 & 4 & 4 & 38 \\
\hline 14 & 4 & 5 & 4 & 5 & 4 & 3 & 2 & 3 & 4 & 4 & 38 \\
\hline 15 & 4 & 5 & 4 & 5 & 4 & 3 & 2 & 3 & 4 & 4 & 38 \\
\hline 16 & 4 & 5 & 4 & 5 & 4 & 3 & 2 & 3 & 4 & 4 & 38 \\
\hline \multicolumn{11}{|c|}{ Total Skor } & 266 \\
\hline \multicolumn{11}{|c|}{$\begin{array}{c}\text { Daftar pernyataan terkait pengetahuan tentang } \\
\text { Asessmen psikososial }\end{array}$} & \\
\hline 17 & 4 & 5 & 4 & 5 & 4 & 4 & 4 & 5 & 4 & 4 & 43 \\
\hline 18 & 4 & 4 & 4 & 5 & 4 & 4 & 4 & 5 & 4 & 5 & 43 \\
\hline 19 & 5 & 5 & 4 & 5 & 4 & 3 & 4 & 5 & 4 & 4 & 43 \\
\hline \multicolumn{11}{|c|}{ Total Skor } & 129 \\
\hline \multicolumn{11}{|c|}{ ftar pertanyaan terkait praktik Asessmen psikososial } & \\
\hline 20 & 3 & 3 & 3 & 1 & 3 & 2 & 3 & 2 & 1 & 3 & 24 \\
\hline 21 & 3 & 3 & 3 & 1 & 1 & 2 & 2 & 2 & 2 & 3 & 22 \\
\hline 22 & 2 & 2 & 3 & 2 & 1 & 2 & 1 & 2 & 2 & 1 & 18 \\
\hline 23 & 2 & 2 & 3 & 2 & 2 & 2 & 3 & 2 & 2 & 1 & 21 \\
\hline 24 & 3 & 0 & 3 & 3 & 3 & 2 & 3 & 2 & 2 & 3 & 24 \\
\hline \multicolumn{11}{|c|}{ Total Skor } & 109 \\
\hline
\end{tabular}

Nilai Tertinggi

$=1130$

Nilai Terendah

$=10 \times 40=400$

Kelas Interval

$$
=\underline{1130-400}=
$$$$
\underline{730}=244
$$$$
3
$$

Penilaian :

$$
\begin{aligned}
\square \text { Rendah } & =400-644 \\
\square \text { Sedang } & =645-889 \\
\checkmark \text { Tinggi } & =890-1134
\end{aligned}
$$

Dari penghitungan di atas, dapat dilihat Rekapitulasi Instrumen Penelitian Layanan Dukungan Psikososial berada pada penilaian 890 - 1134 yang berarti tinggi.

Adapun bentuk dan gambaran model akhir

\begin{tabular}{|c|c|c|c|c|c|c|c|c|c|c|c|}
\hline \multicolumn{11}{|c|}{$\begin{array}{c}\text { Daftar pertanyaan terkait pengetahuan tentang } \\
\text { kemampuan relawan dalam menerapkan Prinsip } \\
\text { pelaksanaan layanan dukungan psikososial }\end{array}$} & \multirow[b]{2}{*}{29} \\
\hline 25 & 3 & 4 & 3 & 3 & 3 & 2 & 3 & 2 & 3 & 3 & \\
\hline 26 & 3 & 3 & 3 & 3 & 3 & 2 & 3 & 2 & 2 & 3 & 27 \\
\hline 27 & 3 & 3 & 3 & 3 & 2 & 2 & 3 & 2 & 3 & 3 & 27 \\
\hline 28 & 3 & 4 & 3 & 3 & 2 & 2 & 3 & 3 & 4 & 3 & 30 \\
\hline 29 & 3 & 4 & 3 & 3 & 3 & 2 & 3 & 3 & 3 & 3 & 30 \\
\hline 30 & 3 & 3 & 3 & 3 & 3 & 2 & 3 & 2 & 3 & 3 & 28 \\
\hline 31 & 3 & 3 & 3 & 3 & 3 & 2 & 3 & 3 & 4 & 3 & 30 \\
\hline 32 & 3 & 3 & 3 & 3 & 2 & 2 & 3 & 3 & 4 & 3 & 29 \\
\hline 33 & 3 & 3 & 3 & 3 & 3 & 2 & 3 & 4 & 3 & 3 & 30 \\
\hline \multicolumn{11}{|c|}{ Total Skor } & 260 \\
\hline \multicolumn{11}{|c|}{$\begin{array}{l}\text { Daftar pertanyaan terkait pengetahuan tentang } \\
\text { kemampuan relawan dalam menerapkan teknik } \\
\text { layanan dukungan psikososial }\end{array}$} & \\
\hline 34 & 3 & 3 & 3 & 3 & 3 & 2 & 3 & 2 & 2 & 3 & 27 \\
\hline 35 & 3 & 3 & 3 & 3 & 3 & 3 & 3 & 2 & 3 & 3 & 29 \\
\hline 36 & 3 & 3 & 4 & 3 & 3 & 3 & 3 & 3 & 3 & 3 & 31 \\
\hline 37 & 3 & 2 & 3 & 3 & 2 & 2 & 3 & 2 & 2 & 3 & 25 \\
\hline 38 & 3 & 3 & 3 & 3 & 3 & 3 & 3 & 2 & 2 & 3 & 28 \\
\hline 39 & 3 & 3 & 2 & 3 & 3 & 2 & 3 & 2 & 2 & 3 & 26 \\
\hline 40 & 3 & 2 & 3 & 3 & 3 & 2 & 3 & 2 & 3 & 3 & 27 \\
\hline \multicolumn{11}{|c|}{ Total Skor } & 193 \\
\hline \multicolumn{11}{|c|}{ Total Skor seluruh Aspek } & 1130 \\
\hline
\end{tabular}
berupa Aplikasi Layanan Dukungan Psikososial Rewalan BAZNAS Provinsi Jawa Barat, sebagai berikut :

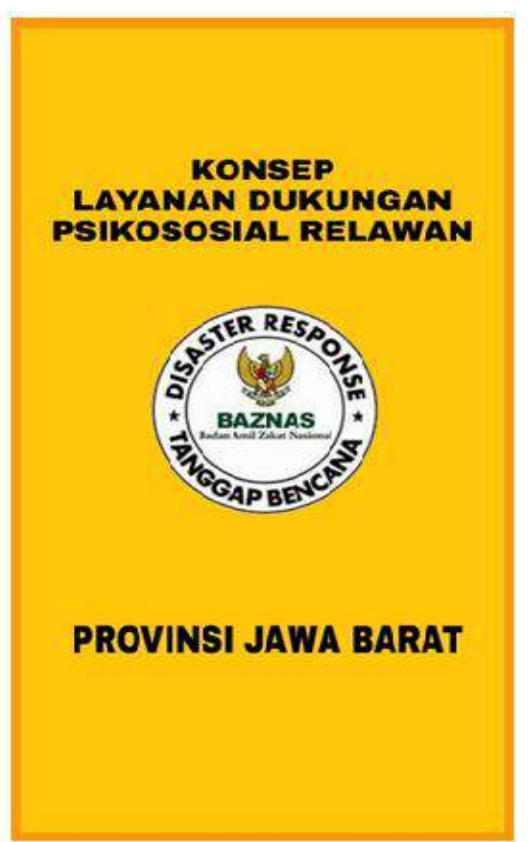

Gambar 1. Cover Aplikasi Layanan Dukungan Psikososial BAZNAS Tanggap Bencana Provinsi Jawa Barat 


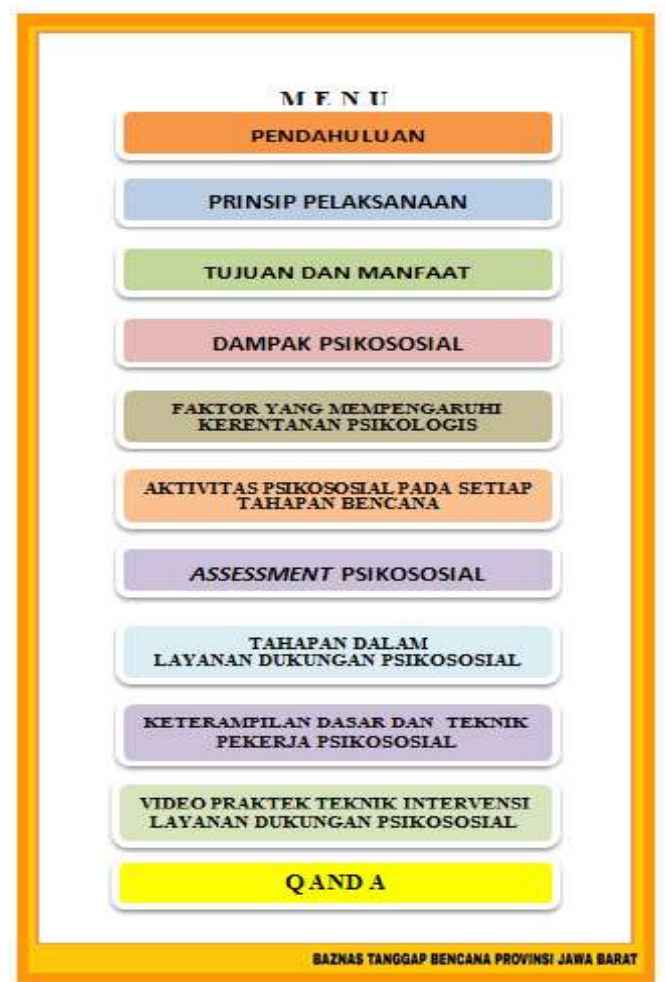

Gambar 2. Halaman ke-1 Menu

\section{PENDAHULUAN}

Indonesia merupakan salah satv negara yang rentan terdampakbencana Pemberian Dukungan Psikososia meru pakan bentuk intervensi sosial yang s aat ini menjad fokus untukdikembangkandalam strategi pengurangan risiko bencanadi Ind conesia sebagaimana tertyang pad a risiko bencanadi nonesia, seb agaimana tertu ang pad Undang-Undionor 24 Tahu 2007, tentang Penanggulangan Bencana, khususnya Pasal 6 dan pas al 8 yang telah mengamanatkan bahw tanggung $j a w a b$ Pemerintah dan Pemerintah Daerah
dalam penyelenggaraan penanggulangan bencana.

Pengertian dukungan sendiri adalah bentuk sebuah suport kepada seseorang atav suatu perhatian,

penghargaan sehingga layanan dukungan psikososial dapat diartikan sebagai banty an yang diberikan kepad individy dan masyaraleat yang mengalami gangenan an ini dilakulan secara terus menerus dan saling mempengaruhi antara aspek psikologis dan aspek sosial dalam lingkungan dimana individu atav masyarakcatberada, yang diberikan kepada individu dan berfungsi sebagai memotivasi.

Sed angkan konseppsikos osial terdiri dari dua hal, yaitu "psiko" dan "sosial". Kata psiko mengacu pada jiwa, pikiran, emosi atav perasaan, perilaku, hal-hal yang divakini, silap penepsidanpemahaman acan din. Ka diyalkini, silapp persidan pemahaman akan din. Kata sosial nenuelerma ani atav religi serta keyakinan yang berlaku dalam suatu mas yaralat $P_{s}$ ikososial diartikan sebagai hubungan yang dinamis dalam interaksi antara mamusia, dimana tingkah lakv, pikiran dan emosi individv akan mempengaruh dan dipengaruhi oleh orang lain atav pengalamansosial.

BAZMAS TANGGAP BEKCANA PROVINSI JAWA BARAT

Gambar 3. Halaman ke-2 Pendahuluan

\section{PRINSIP PELAKSANAAN}

Dalam Buku Saku Layanan Dulungan Paikososial (LDP) Penanganan Bencana Sosial, Dit.PSKBS Kementerian Sosial, menjelastan beberapa prinsip pelals anazn Layanan Dukungan Psikos osial. Antara lain sebagai berikut :

1. Penerimaan (accoptance). Penerimaan adalah menghargai keberadaan dan kondisisituasi korban, saat diterima dan tetap dianggap sebagai manusia yang mempunyai harkat dan

2. Individu alis as (individualization), b ahw a korb an meru palan pribadi yang unik yang penanganannya harus dibedakan

3. Sikap tidak menghakimi (non-judgemental attitude), bahwa tim tidak memberikan penilaian yang bersifat menghakimi para korb an baik tingkah laku mau pun kedudukan.

4. Kerahasiaan (confidentialitv), bahwa tim harvs menjaga kerahasiaan data/informasi perihal korban kepada orang lain kecuali untukkepentingan LDP para korban.

5. Empati (enpathv). Empati adalah kemampuan para petugas dalam memahami apa yang diras akan oleh para korb an yang dapat dijadilan sebagai pertimbangan dalam proses pemberianLDP yang sedang dilakukan.

6. Rasional (rationality), bahwa LDP yang dilakukan harus didasarkan pada pandangan obyektif dan faktual terhadap kond isi permasalahan yang dihad api oleh para korban.

7. Ketuhsankesungguhan (genuineness), bahw a LDP yan dilakukan harus didasarkan pada sikap ketulus an dan kesunggu han tanpa mengharapkan imbalan apapun dari para korban.

8. Kejujuran (impartiality), bahwa LDP yang diberikan harus dilakukan secara jujur tanpa ada kepentinggan apapun kecuali harya untuk kepulihan para korban, tidak menganak-emaskan atav meng-anak-tiri-kan para korban.

9. Mawas diri (self-awareness), bahwa para petugas harus mampu mengendalikan diri secara emosial dalam pemberian LDP yang dilakulan serta menyadari akan potensi dan keterbatas an yang dimiliki oleh para korban

BAZNAS TANGGAP BENCAKA PROVINSI JaWA BARAT

Gambar 4.Halaman ke-3 Prinsip Pelaksanaan

TUJUAN DAN MANFAAT

Tujuan LDP adalah untuk meningkatkan kesejahteraan psikososial bagi penyintas, diantaranya.

a. Sejahtera dapat diasosiasikan dengan rasa telah memiliki semua yang dibutuhkan, sempurna, menikmati hidup, berhasil mengatasi tantang an, memiliki daya tahan, dan lain sebagainya.

b. Kesejahteraan psikososial ditandai dengan dimilikinya sejumlah kompetensi yang saling berkaitan.

c. Kompetensi psikososial yang harus dimiliki penyintas untuk mencapai kesejahteraan antara lain adalah kemampuan membangun hubungan akrab dengan anggota keluarga, tetangga, teman sebaya; memiliki rasa tanggungjawab; memiliki persahabatan yang bermakna dan keterampilan sosial; rasa percaya kepada orang lain; rasa dimiliki atau menjadi bagian dari keluarga atau komunitas; memiliki harga diri; rasa berdaya; mampu berpartisipasi dan menentukan jalan hidupnya sendiri; mampu memanfaatkan peluang; memiliki harapan dan optimism mengenai masa depannya; kreatif menciptakan berbagai; alternatif pemecahan masalah; mampu menyesuaikan diri terhadap situasi yang dihadapi.

Sedangkan manfaat dari Layanan Dukungan Psikososial sendiri adalah:

a. Membantu individu untuk mengurangi beban emosinya.

b. Mengembalikan fungsi sosial individu di dalam lingkungannya.

c. Meningkatkan kemampuan individu di dalam pemecahan masalah masalah yang dihadapi pasca bencana.

BAZNAS TANGGAP BENCANA PROVINSI JAWA BARAT

Gambar 5. Halaman ke-4 Tujuan dan Manfaat 


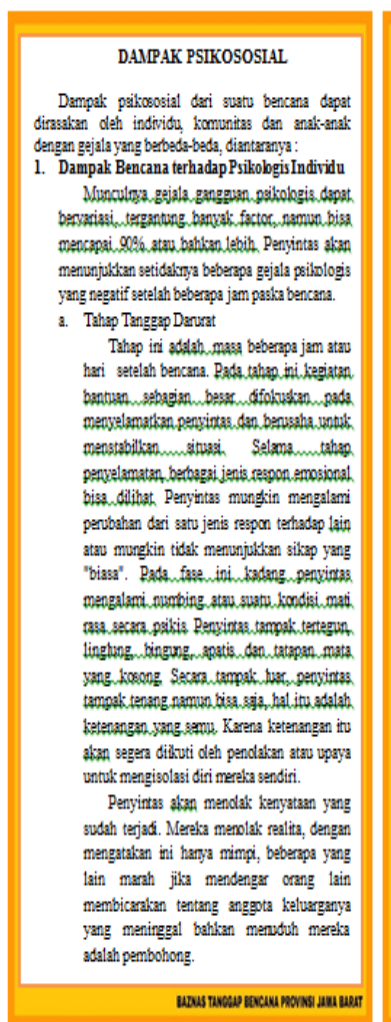

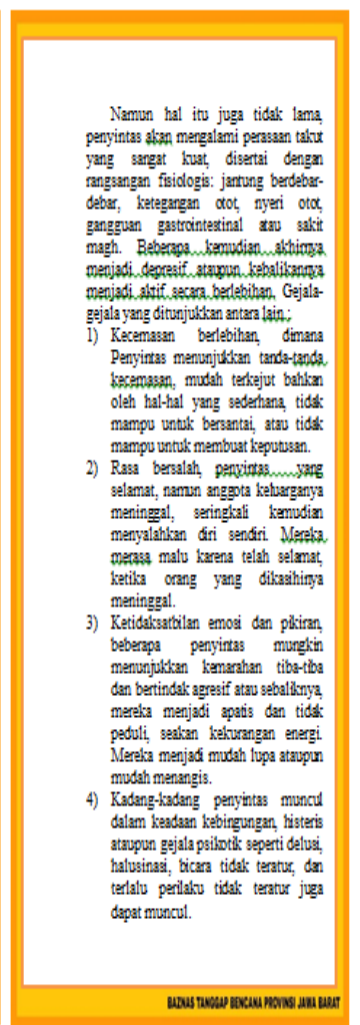

Gambar 6.Halaman ke-4 dan 5 Dampak Psikososial

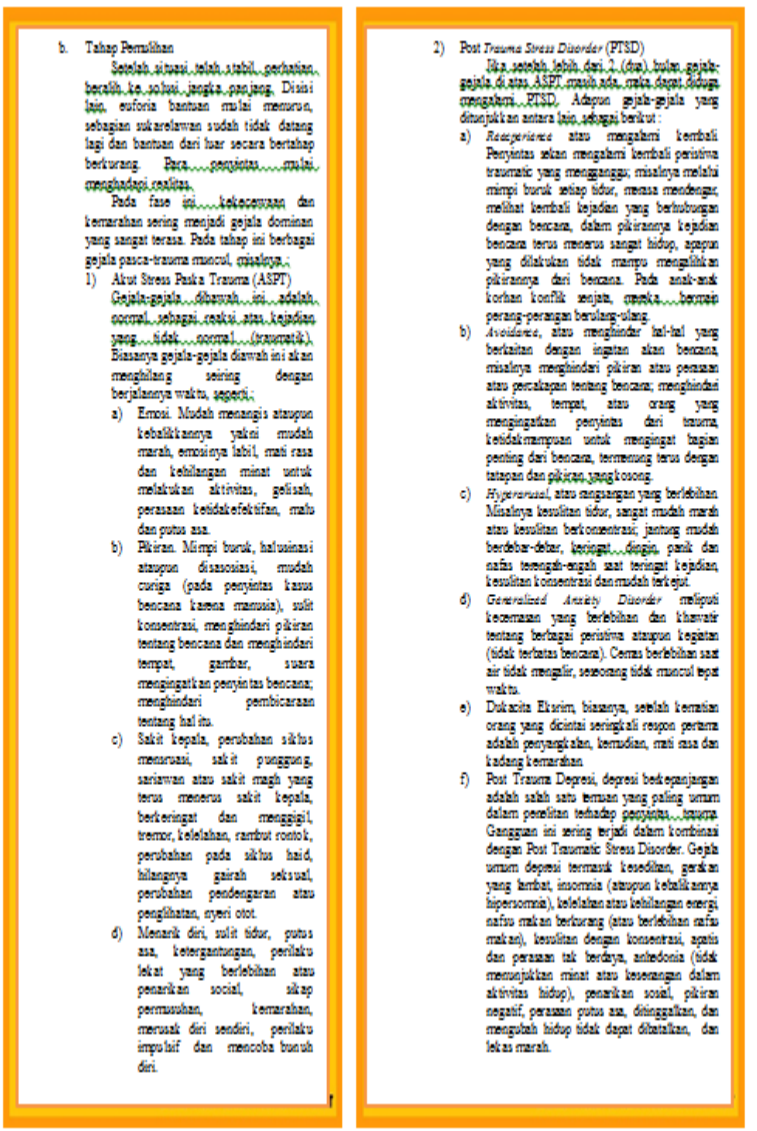

Gambar 7. Halaman ke-6 dan 7 Dampak Psikososial

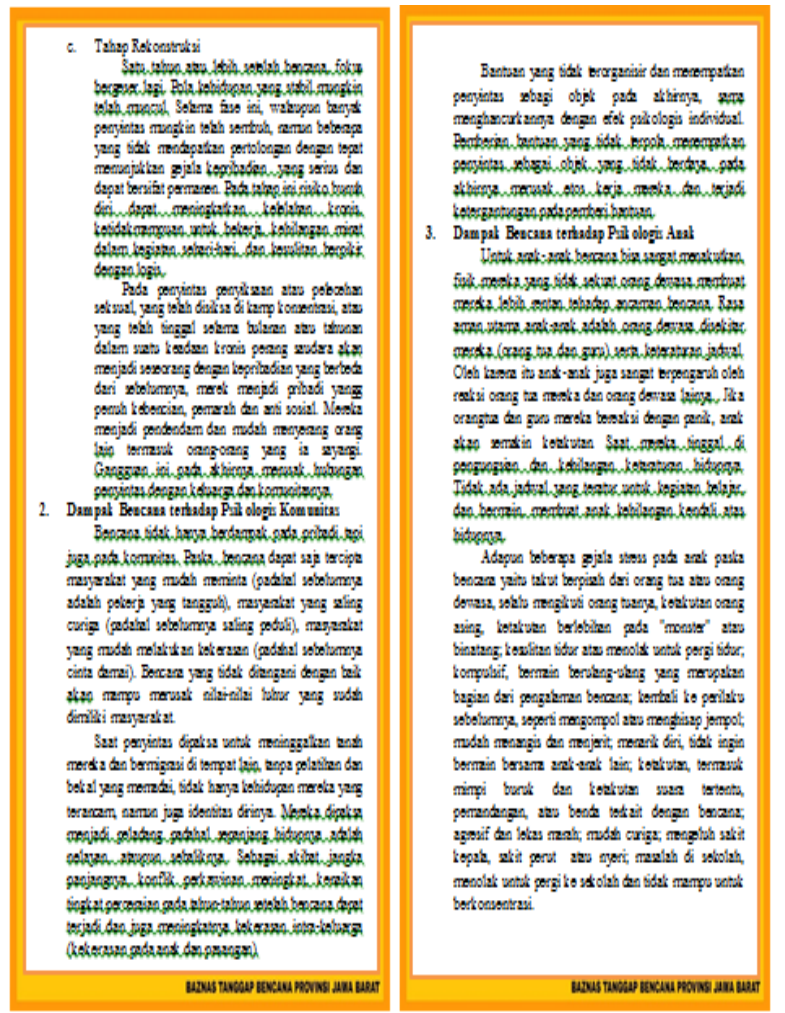

Gambar 8. Halaman ke-8 dan 9 Dampak Psikososial
Gambar 9.Halaman ke-10 dan 11 Faktor yang Mempengaruhi Kerentanan Psikologis 


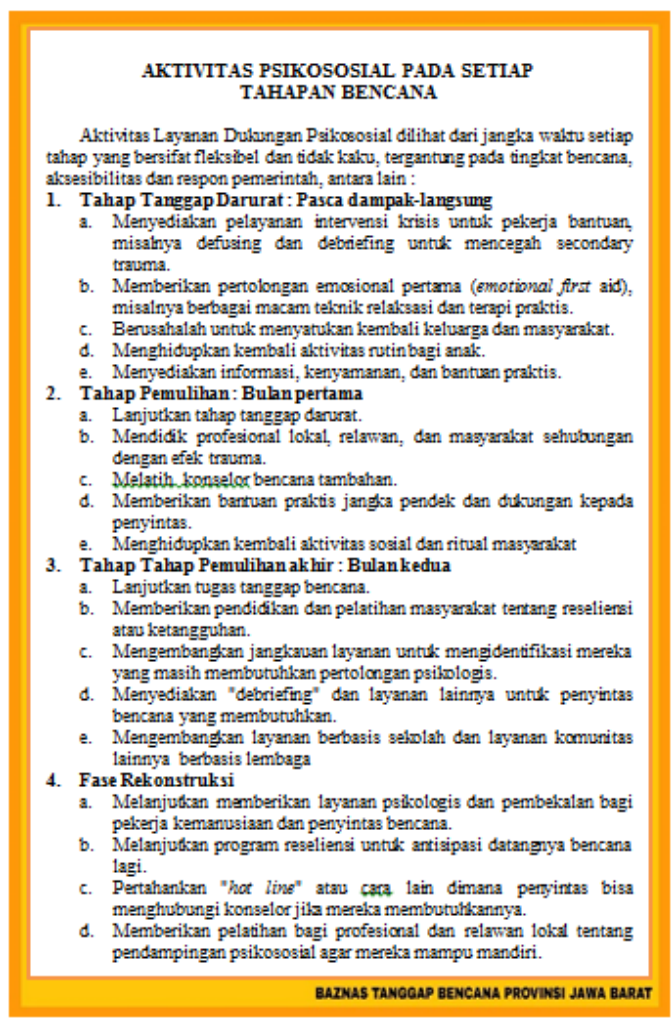

Gambar 10. Halaman ke-12 Aktivitas Psikososial pada setiap Tahapan Bencana

\begin{tabular}{|c|c|}
\hline 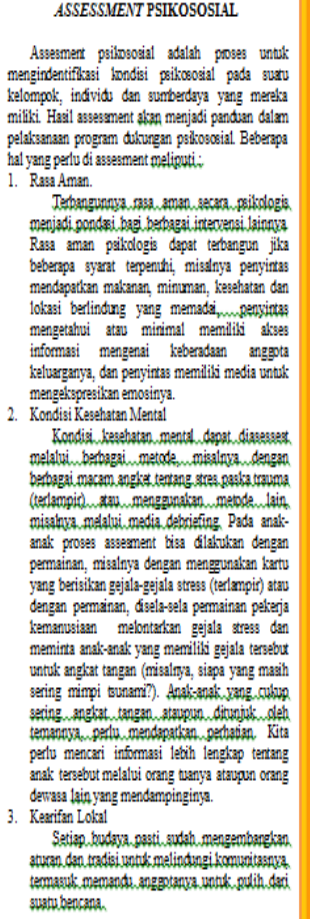 & 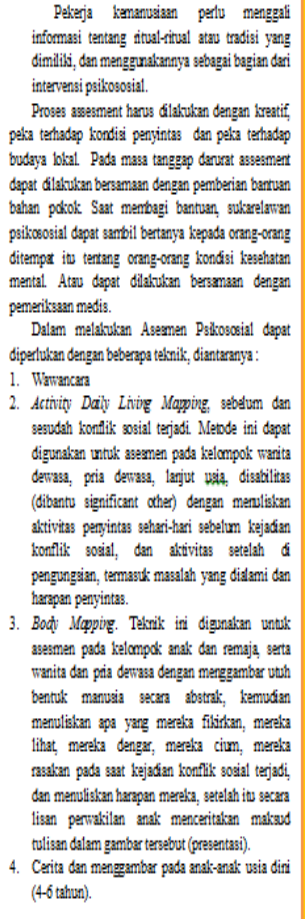 \\
\hline 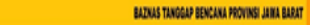 & 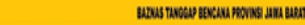 \\
\hline
\end{tabular}

Gambar 11. Halaman ke-13 dan 14 Assessment Psikososial

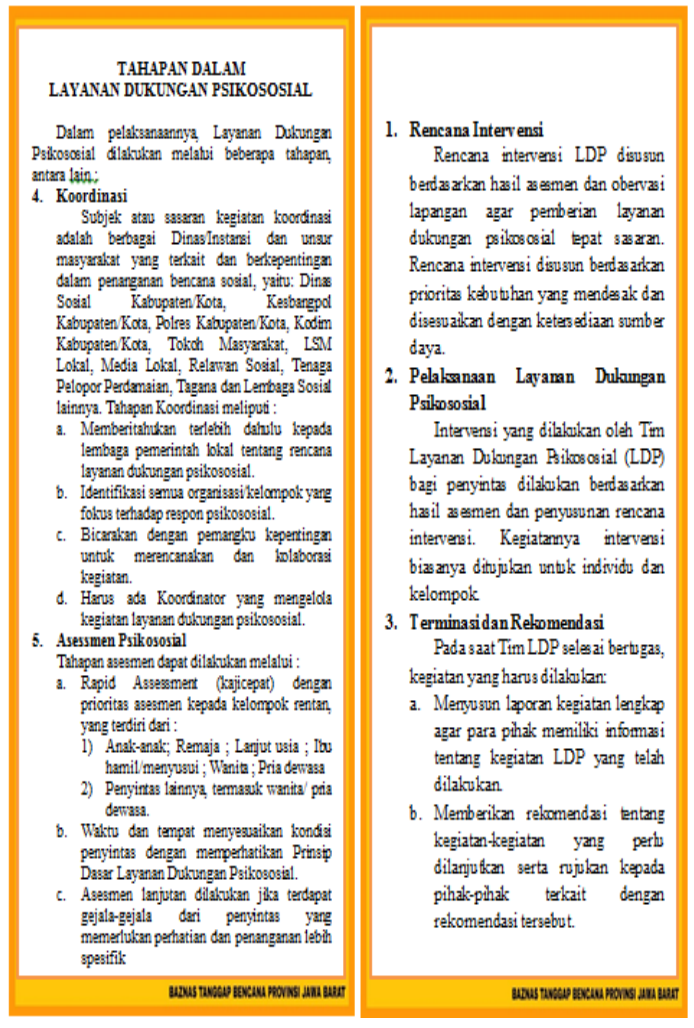

Gambar 12. Halaman ke-15 dan 16 Tahapan dalam Layanan Dukungan Psikososial

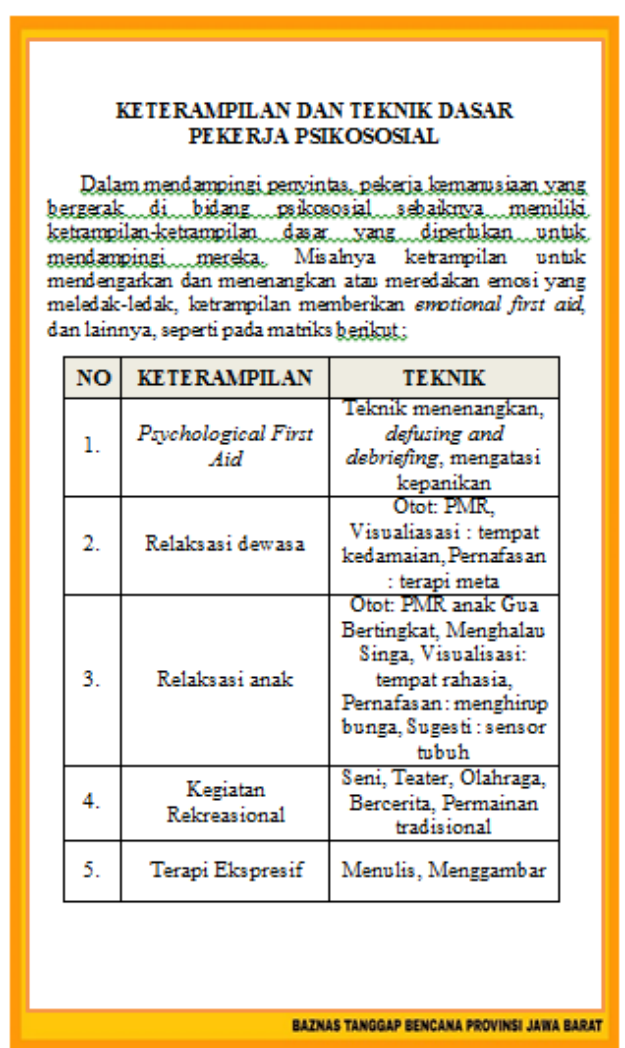

Gambar 13. Halaman ke-17 Keterampilan dan Teknik Dasar Pekerja Psikososial 


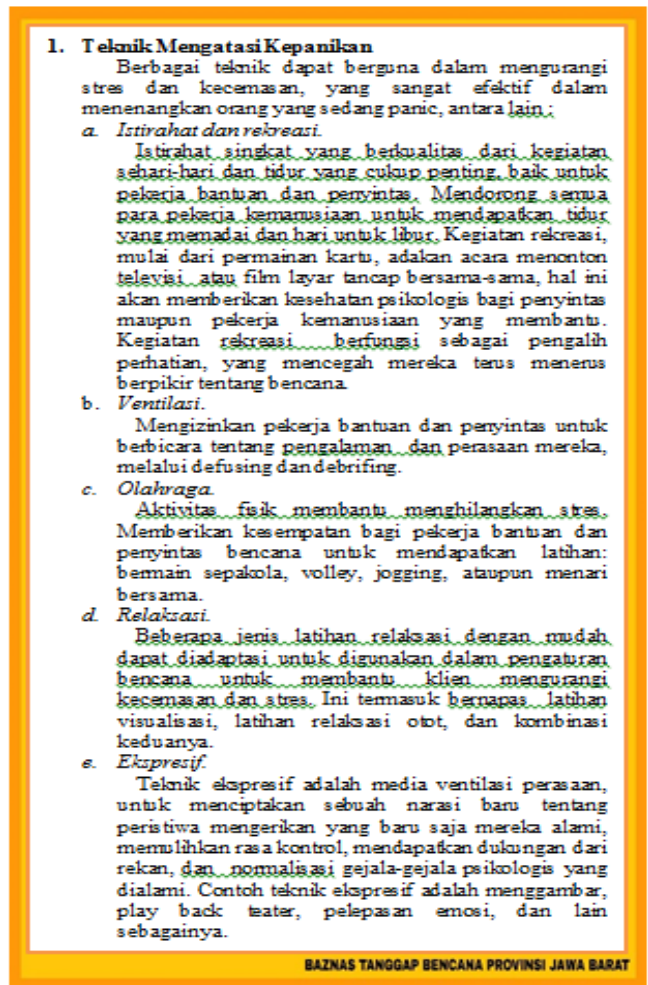

Gambar 14. Halaman ke-18 Teknik Mengatasi Kepanikan

Gambar 15. Halaman ke-19 Teknik Meredakan Emosi

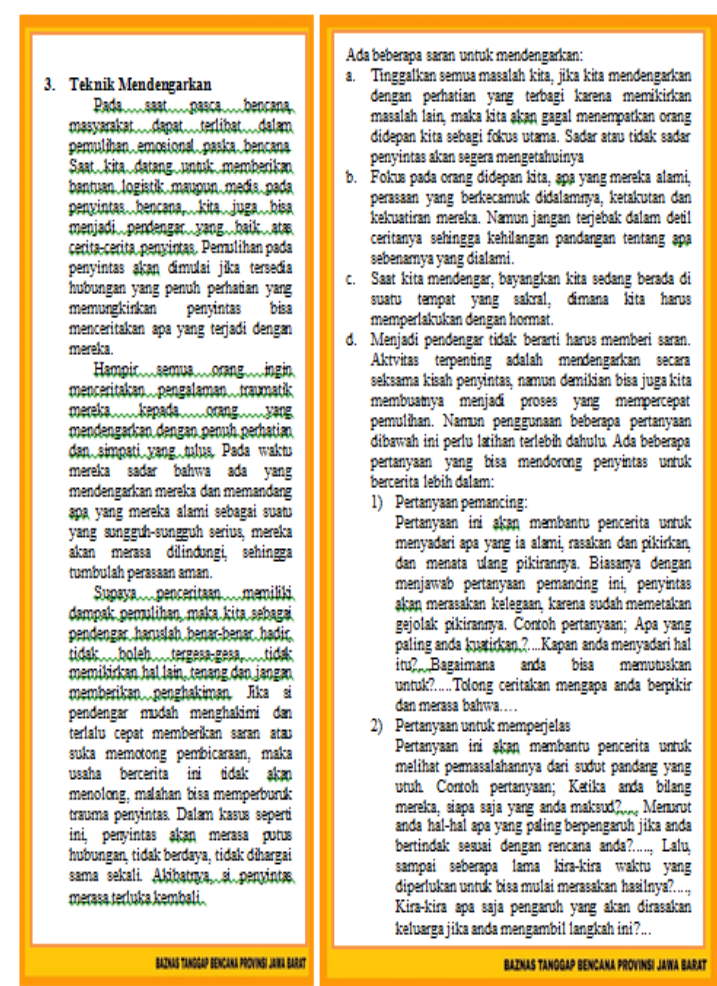

Gambar 16. Halaman ke-20 dan 21 Teknik Mendengarkan

Gambar 17. Halaman ke-22 Teknik Defusing dan Debriefing 


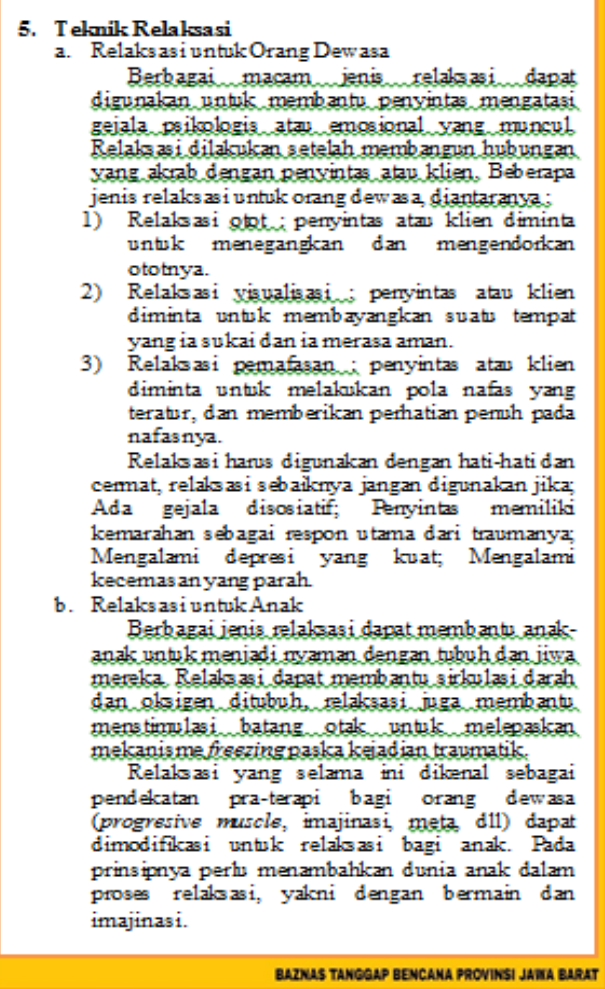

Gambar 18. Halaman ke-23 Teknik Relaksasi

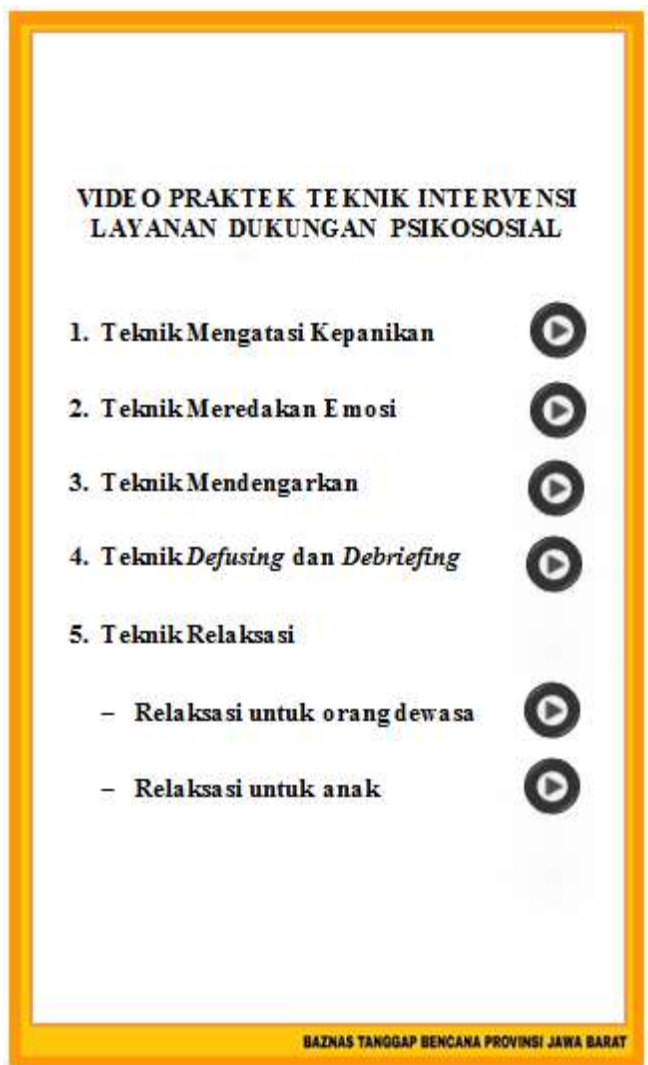

Gambar 19. Halaman ke-24 Video Praktek Teknik Intervensi LDP

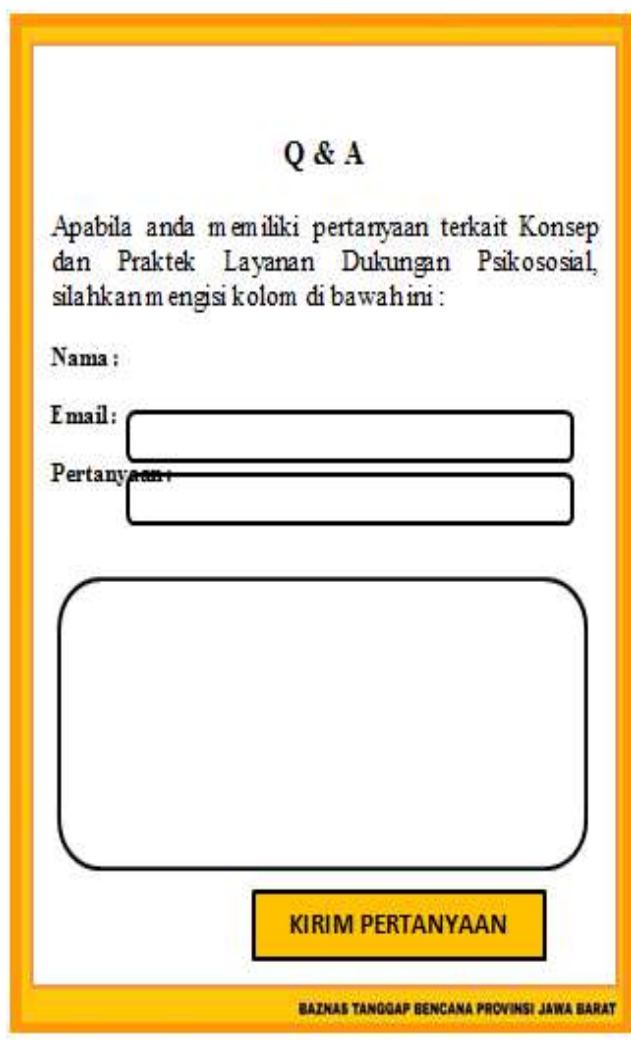

Gambar 20. Halaman ke-25 Kolom Pertanyaan

\section{KESIMPULAN}

Penelitian tentang Teknologi Peningkatan Kemampuan Relawan Dalam Pemberian Layanan Dukungan Psikososial di Badan Zakat Amil Nasional (BAZNAS) Tanggap Bencana Provinsi Jawa Barat ini lebih mengutamakan terciptanya teknologi yang dapat mempermudah para relawan BAZNAS Tanggap Bencana dalam mengakses secara mobile tentang konsep dan teknik dalam melakukan Layanan Dukungan Psikososial. Hal ini didasari oleh kegiatan para relawan yang lebih banyak berada di lapangan, sehingga tidak memungkinkan untuk diadakannya pelatihan secara langsung dan rutin.

Penelitian ini dilakukan dengan menggunakan instrumen wawancara berupa angket, untuk mengukur tingkat kemampuan para relawan dalam memahami Layanan Dukungan Psikososial. Sedangkan metode yang digunakan adalah metode data sekunder. Sasaran dalam penelitian adalah para Relawan BAZNAS 
Tanggap Bencana. Proses pelaksanaan sebelumnya telah melalui pelatihan Layanan Dukungan Psikososial secara langsung, namun beberapa kendala yang mampengaruhi kelanjutan penelitian ini menjadi hambatan untuk melanjutkan pelaksanaan Pelatihan Layanan Dukungan Psikososial.

Berdasarkan hal tersebut peneliti merekomendasikan Aplikasi Konsep Layanan Dukungan Psikososial Relawan BAZNAS Tanggap Bencana yang disusun berdasarkan teori-teori dan konsep yang telah ada dari para ahli di bidang psikososial yang di jadikan dalam satu wadah. Aplikasi ini berisikan Definisi Dukungan Psikososial; Prinsip Pelaksanaan; Tujuan dan Manfaat; Dampak Psikososial; Faktor yang Mempengaruhi Kerentanan Psikologis; Aktivitas Psikososial pada setiap tahapan bencana; Assessment Psikososial; Tahapan dalam Dukungan Psikososial; Keterampilan Dasar dan Teknik Pekerja Psikososial.

Meskipun dengan adanya Aplikasi ini para relawan wajib diberikan pelatihan secara langsung secara berkala atau dapat di kondisikan dengan kegiatan para relawan, agar dapat lebih mengasah kemampuan dan bertukar pikiran serta pengalaman yang terjadi selama di lapangan. Selain itu dukungan besar berupa anggaran dari Badan Zakat Amil Nasional Provinsi Jawa Barat yang menaungi BAZNAS Tanggap Bencana sangat di perlukan untuk menunjang terwujudnya kegiatan ini.

\section{REKOMENDASI}

Berdasarkan kesimpulan tentang Teknologi Peningkatan Kemampuan Relawan Dalam Pemberian Layanan Dukungan Psikososial di Badan Zakat Amil Nasional Tanggap Bencana Provinsi Jawa Barat, maka peneliti mengajukan saran atau rekomendasi kepada BAZNAS Tanggap Bencana Provinsi Jawa Barat dan Relawan
BAZNAS Tanggap Bencana agar penelitian ini dapat berkelanjutan (sustainable). Adapun rekomendasi tersebut terkait tiga hal, yaitu :

a. Adanya dukungan lebih berupa anggaran dari BAZNAS dalam memfasilitasi BAZNAS Tanggap Bencana Provinsi Jawa Barat dalam proses implementasi mulai dari perencanaan dan penyusunan, serta pelaksanaan agar kebutuhan kegiatan dapat lebih terperinci, sehingga dapat mewujudkan penggunaan Aplikasi Konsep Layanan Dukungan Psikososial Relawan BAZNAS Tanggap Bencana.

b. Selain itu, dalam uji coba Aplikasi ini, peneliti berharap agar para relawan BAZNAS Tanggap Bencana Provinsi Jawa Barat dapat juga mempraktikkan teknikteknik yang ada di dalamnya secara langsung dilapangan, maka dari itu sangat penting untuk relawan mengikuti pelatihan Layanan Dukungan Psikososial secara langsung, karena meskipun bersifat mobile dan praktis ilmu Teknik Layanan Dukungan Psikososial harus diberikan oleh para narasumber yang berkompeten di bidangnya dan tidak cukup hanya dengan sekali pelatihan, maka dukungan dari BAZNAS dan BAZNAS Tanggap Bencana sangat penting dalam pelaksanaan pelatihan hingga uji coba aplikasi ini.

c. Aplikasi Konsep Layanan Dukungan Psikososial Relawan BAZNAS Tanggap Bencana ini merupakan alternatif bagi BAZNAS Tanggap Bencana untuk dapat meningkatkan pengetahuan dan kemampuan relawan secara mobile jika pelatihan tidak dapat dilaksanakan secara rutin. Untuk kelanjutannya, peneliti berharap akan ada peningkatan dalam penggunaan aplikasi ini baik untuk relawan dan penyintas. Mengingat para relawan memiliki potensi terpapar permasalahan psikososial di lokasi bencana, maka Aplikasi ini dapat juga digunakan untuk 
membantu relawan mengatasi permasalahan psikososial di lapangan, dengan menerapkan teknik-teknik yang tersedia di dalamnya. Selain itu relawan dapat memperhatikan kebutuhan dari permasalahan yang penyintas hadapi dan rasakan, agar hasil yang didapatkan bisa benar-benar bermanfaat bagi kelangsungan psikososial para penyintas.

\section{DAFTAR PUSTAKA}

Adi, S. Pengertian Peningkatan Menurut Ahli. (11 Februari 2020), Http://www.Duniapelajar.Com.pengertianPeningkatan-Menurut-Para-Ahli.Html

Anni Millen. 2004. Pegangan Dasar Pengembangan Kapasitas. Diterjemahkan Secara Bebas. Yogyakarta: Pondok Pustaka Jogja.

BNPB. 2012 .Buku Saku Tanggap Tangkas Tangguh Menghadapi Bencana.

PSKBS Kementerian Sosial RI., 2018. Buku Saku Layanan Dukungan Psikososial (LDP) Penanganan Bencana Sosial,

Fadhli, Aulia. 2019. Mitigasi Bencana, Yogyakarta : Penerbit Gava Media

Ichwan Muis, 2015. Partisipasi Pressure Group dalam Proses Penetapan Kebijakan Manajemen Penanggulangan Bencana di Lembaga Permasyarakatan Anak Kelas III Bandung. Bandung. KIKA STKS Bandung.

Khambali (Ed). 2017. Manajemen Penanggulangan Bencana, Yogyakarta :Penerbit Andi

Kharismawan, Kuriake. (2008). Panduan Program Psikososial Paska Bencana. Semarang: Center For Trauma Recovery Unika Soegijapranata

Moleong, Lexy J.. 2007. Metodologi Penelitian Kualitatif. Bandung: Remaja Rosdakarya.

Novi Hendrika Jaya Putra, 2011. Model Pengurangan Risiko Bencana Berbasis Keluarga di Kelurahan Lempuing Kota Bengkulu. Bandung. KIKA STKS Bandung.

Pemerintah Provinsi Jawa Barat, Kondisi Geografis Provinsi Jawa Barat (15 Februari 2020) https://jabarprov.go.id/index.php/pages/id/13 $\underline{61}$

PMI, Pengertian Relawan, (12 Februari 2020),

https://pmisumut.or.id/apa-itu-relawan/

Salamadian, "Pengertian Teknologi", 2018, (13 Februari 2020 )

(https://salamadian.com/perkembanganpengertianteknologi/)

Sriyanto, Pengertian Kemampuan, (11 Februari 2020), http://ian43.wordpress.com/2010/12/23/peng ertian-kemampuan/

Suprapto, 2011. Model Peningkatan Kesiapsiagaan Masyarakat dalam Pengurangan Risiko Bencana Alam Banjir di RW 11 Kelurahan Rawa Buaya, Kecamatan Cengkareng Jakarta Barat. Bandung. KIKA STKS Bandung.

Sugiyono. 2010. Metode Penelitian Pendidikan Pendekatan Kuantitaf, Kualitatif, dan R\&D. Bandung: Alfabeta.

Stringer, Ernest T. 2007. Action Research. Third Edition. USA : Sage Publication

Suwarsih Madya, 2011. Penelitian Tindakan (Action Research). Bandung : Alfabeta

Tukino. 2013. Peran Pekerja Sosial dalam Setting Kebencanaan Jurnal Pekerjaan Sosial, (12 Februari 2020) http://jurnal.unpad.ac.id/share/article/view/1 $\underline{0020}$

Tungga E.M Yeane, dkk. 2013. Terapi Psikososial Suatu Pengantar. Bandung: STKSPress

Undang-Undang Republik Indonesia Nomor.24 Tahun 2007.

Wanaswara, 2019. "Pengertian Relawan, Definisi, dan Pendapat Ahli" (13 Februari 2020) https://wanaswara.com/pengertianrelawan/\#Pengertian_Relawan 